\title{
AN INVESTIGATION OF THE PERCEPTIONS OF SOUTH AFRICAN STUDENTS WITH REGARDS TO ACCELERATED LEARNING COURSES
}

\author{
L. M. Van Rooyen* \\ e-mail: vanrooyen.lynn@gmail.com / https://orcid.org/0000-0003-4722-3319
}

\author{
J. M. Ontong* \\ e-mail: ontongi@sun.ac.za / https://orcid.org/0000-0001-5097-8988
}

\section{Z. L. Mitchell*}

e-mail: zurelda@sun.ac.za / https://orcid.org/0000-0002-3831-4131

\author{
*School of Accountancy \\ Stellenbosch University \\ Stellenbosch, South Africa
}

\section{ABSTRACT}

The cost of repeating a module has both financial and social implications. The social implications include increased workloads when repeating a module and students often not being able to graduate within the prescribed minimum course period. A possible solution for this is the use of accelerated learning courses, in the form of summer or winter schools. These schools provide students with another opportunity to pass a module, during the summer or winter recess, using an accelerated learning mode, and consequently complete modules with prerequisites of failed modules in the following year. Using an accelerated learning approach, a summer or winter school covers a large portion of the content in semester or year modules in a shortened timeframe outside the normal academic period. Using a questionnaire approach, the various perceptions of first year students at the end of the academic year regarding the use of these schools were obtained and analysed. The timing of the end of the academic year allows students to familiarise themselves with the various accelerated learning courses offered to them throughout the academic year. The findings suggest that students have a positive perception of these schools despite most of them not having had previous experience of completing an accelerated learning course. Although previous literature has indicated that students are hesitant to complete finance-related modules in an accelerated learning format versus traditional semester and year modules, the perceptions indicate that students are willing to engage in financial modules, with the students identifying that the benefits of these accelerated learning courses exceed the cost. The findings suggest that students who are presented with various non-academic obstacles throughout the traditional module are able to use summer or winter schools as a way to reduce exposure to these obstacles and complete an accelerated learning course. The use of these schools therefore presents an 
area for module developers to consider when implementing these schools as a way to improve throughput rates, thereby contributing in a positive way to students' financial and social health.

Keywords: accelerated learning, first year students, financial accounting, summer and winter schools

\section{INTRODUCTION}

At the beginning of each year, it has become the norm to read frequent media reports of prospective students meeting university admission criteria but not being able to enrol at universities due to a lack of registration capacity (The Skills Portal 2017; Seeth 2017). Although the expansion in student enrolment and the increase in first-year enrolments in particular indicate a major improvement in access to higher education in South Africa, this has caused many challenges for South African universities. One of these challenges is the overcrowding of many South African universities in respect of classes and student venues (Macupe 2019; Xala 2019). Additionally, a barrier to university entry is the increasing high cost of tertiary education and the funding problems experienced by students as brought to light by the 2015/2016 \#FeesMustFall protests (Naidoo and McKay 2018). Lack of funding creates a further barrier to first-time students' access to higher education, as well as the ability to complete their studies (Naidoo and McKay 2018).

\section{INCREASE IN MATRICULANTS WHO QUALIFY FOR ADMISSION TO UNIVERSITY}

The Grade 12 pass rate has seen an overall increasing trend over recent periods (Business Tech 2019; Prior 2019). The Grade 12 pass rate figures for the class of 2019 was 81.3 per cent (Etheridge 2020), which represents a 3 per cent increase from the previous year. More so, the number of matriculants who obtain a bachelor's pass and obtained admission into universities improved by 8 per cent from 2018 (Marriah and Mlambo 2020). As stated by the Minister of Basic Education, Angie Motshekga, "the 2019 Bachelor passes in number and percentage are the highest attained in the entire history of the NSC [National Senior Certificate] examinations" (in Marriah and Mlambo 2020). There has recently been an increase in bachelor's passes despite there being fewer matriculants writing the NSC examinations, as previously identified by Spaull (2019). A contributing factor to the increase in the number of matriculants who qualify for a bachelor's pass is the recent change to the criteria for obtaining a bachelor's pass by abolishing the "designated subject" list, which resulted in matriculants being able to obtain 50 per cent in any subject (Government Gazette 2018; Spaull 2019). Subjects such as Computer Applications Technology, Dance, and Hospitality (among others) have a high enrolment and the pass rate for 
these subjects is high (Spaull 2019). Although these subjects may limit the field of study at university, they still grant matriculants access to study at university (Department of Basic Education 2019). This results in an increase in the number of matriculants who qualify for university entrance; of whom many will not be able to be accommodated (Spaull 2019). South African universities continue to accept a fraction of applications due to the over-subscription of first-time university applicants (The Skills Portal 2017). This increase in matriculants suggests increased potential student enrolments, potential massification, at higher education institutions. Although this increase in students' numbers could potentially create tensions with student retention and student success.

Supporting this concept of increased demand at higher education institutions, the number of students enrolled at universities has nearly doubled since 1994 (MacGregor 2014), when approximately 500000 students were enrolled (Tjønneland 2017). Universities have experienced substantial increases in enrolments, particularly from 2002 to 2016, and more recently as well (Statistics South Africa [Stats SA] 2017). It is however noted that universities are still under pressure to admit more students (Muller 2017). According to Stats SA (2017), there has not been a significant increase in first-time university undergraduate enrolments in accordance with the continuous increase in bachelor's passes, which indicates that South African universities are experiencing challenges in placing matriculants due to limited placements available (Business Tech 2018).

In the South African context, as quoted by Mohamedbhai $(2014,1)$, "most public higher education institutions in Africa, in response to historical conditions, have enrolled students in excess of their capacity, resulting in massification and negative consequences on educational quality". South Africa has followed suit and South African public universities have experienced a significant increase in student enrolments in higher education in order to remedy historical injustice by increasingly including groups that were previously excluded or marginalised (Muller 2017). Besides limitation of space requirements for students in Higher education institutions further concerns are noted about the massification of higher education.

The tensions between massification and student retention success originate from various sources such as, university financing constraints, as well as limited capacity and infrastructure (Makou, Wilkinson, Bhardwaj and Skosana, cited by Africa Check 2016; Centre for Chinese Studies 2014; MacGregor 2014; Stats SA 2018). Various studies have been performed assessing factors that influence student success, notably most of these interventions such as additional classes, tutoring and mentoring require the availability of resources (Baard, Steenkamp, Frick and Kidd 2010). It is therefore noted that the masification of classes could act as a potetial inhibitor of student success. 


\section{STUDENT FUNDING CONSTRAINTS}

Student funding constraints result in many potential and existing students being excluded from higher education as a result of not having sufficient funds (Naidoo and McKay 2018). The high costs of delivering higher education and the reduced national budget towards the running costs of universities have further put pressure on students to share in the costs of university funding, since the South African university funding framework is based on costs shared between beneficiaries, which are the government and students ( $P w C$ 2015). This student funding crisis made headlines through the 2015/2016 \#FeesMustFall movement (Naidoo and McKay 2018). As a result, free higher education that would be provided to all new first-year students from families that earn less than R350 000 per year as from 2018 was announced (Muller 2018).

Free higher education for a spectrum of students, however, does not address the funding constraints of students who do not meet these criteria. More so, stringent qualification criteria for the National Student Financial Aid Scheme (NSFAS) funding and limited available student bursaries further place funding constraints on students who do not qualify for such. This results in students without bursaries obtaining funding from sources such as bank loans, part-time work, savings, and parental or family contributions to pay for their studies (Naidoo and McKay 2018). Additional costs associated with higher education such as living expenses, textbooks, and other academic-related costs (such as Internet access), transport, and lifestyle costs further increase the costs associated with higher education (Naidoo and McKay 2018).

The total cost to study at South African public universities ranges from approximately R36 500 to R77 981 after considering inflationary increases and consideration of the degree enrolled for (Stead 2019). The cost of study depends on the cost of the courses enrolled in that make up that degree (Stead 2019). Repeating an entire course as a result of failure of a module will increase study costs and delay the time it takes for students to graduate. Furthermore, the investment in and advancement of students' education towards tertiary education are expected to improve their earning potential and employment prospects (Blöndal, Field, and Girouard 2002); a delay in obtaining a degree in the prescribed timeframe thus reduces this expected earning potential. An additional motive for students to further their education is to lower the risk of unemployment and prolonged participation in the labour market in comparison to those with lower educational attainment (Blöndal et al. 2002).

Numerous factors contribute to students repeating courses and not graduating within the prescribed amount of time; as a result, students delay the above mentioned benefits of tertiary education. Johnston (1997) suggested that the failure of first-year students is mainly due to nonacademic factors such as (1) personal difficulties, (2) financial difficulties, (3) poor health, 
(4) change of course, (5) employment, (6) change of institution, and (7) dislike of the course, more than solely academic problems. Certain factors identified by Johnston (1997) above continue to currently be areas for ongoing debate, such as to whether free education is needed in South Africa. Wangenge-Ouma and Cloete (2008) note that free education grants access to a higher education thus reducing the pressure of students with financial difficulties to potentially achieve academic success. A study by De Jager and Baard (2019) finds however that student respondents do not think that "free" higher education make economic sense in South Africa as the economy is too weak and there is too much corruption and wasteful spending in government. The literature however suggests that providing free education does potentially lead to students being successful in courses as free education should be seen as a favourable investment, especially in developing countries (Shrivastava and Shrivastava 2014).

Petersen, Louw, and Dumont (2009) identified psychosocial variables (seeking help, academic motivation, self-esteem, perceived stress, and perceived academic overload) that influence the success of economically and educationally disadvantaged students' performance at universities in South Africa more than students' academic performance. Naidoo and McKay (2018) indicated that funding alone is not the only solution to tertiary education dropout rates. It has, however, been identified that by providing students with an opportunity to not repeat an entire year module will reduce the financial stress placed on students and allow them to complete their studies in the prescribed time.

A solution that this research focuses on is using summer or winter schools to assist students in completing their studies and graduating in the prescribed time, thus reducing the overall cost of education and aiding increased first-year entry into universities (to a lesser extent) by improving the throughput rate of first-year students. These classes are offered in a time-compressed format.

It is therefore suggested based on the time-compressed format that students could use this alternative format to traditional classes as a measure to reduce the impact of non-academic factors influencing their academic success, therefore increasing their potential to be academically successful in a module. Although the pass rates of accelerated learning courses are not explored as part of this study this provides an opportunity for further research.

Classes offered in a time-compressed format are often referred to as (1) intensive, (2) accelerated, (3) abbreviated, (4) summer/winter, and/or (5) block (Lutes and Davies 2018). Time-compressed courses generally take place over five to six weeks (Hyun, Kretovics, and Crowe 2006) or one to nine weeks (Hesterman 2015) in comparison with regular semester or traditional courses, which are between 12 and 16 weeks (Scott and Conrad 1992) or 15 to 16 weeks long (Hyun et al. 2006). The course format requires the same number of contact hours 
as the traditional class; however, the course hours take place in a shortened timeframe, which results in accelerated completion of coursework or credentials (Edgecombe 2011). The workload of these courses is usually similar to regular semester courses, with minor changes to the course, such as assigned readings, test format, and content being adapted to accommodate the shortened time period of the accelerated course (Lutes and Davies 2018).

Serdyukov (2008) differentiated between accelerated and intensive courses and noted the difference between quantitative change (time) in accelerated courses and both quantitative (time) and qualitative (instructional methods) changes for intensive learning formats. The characteristics of accelerated and intensive courses as indicated by Serdyukov (2008) are summarised in Table 1.

Table 1: Characteristics of accelerated and intensive courses

\begin{tabular}{|l|l|l|}
\hline \multicolumn{1}{|c|}{ Format } & \multicolumn{1}{c|}{ Accelerated course } & \multicolumn{1}{c|}{ Intensive course } \\
\hline $\begin{array}{l}\text { Instructional } \\
\text { methods }\end{array}$ & Same as traditional. & $\begin{array}{l}\text { Effective instructional methods. } \\
\text { The aim is to increase learning efficiency. }\end{array}$ \\
\hline Class hours & $\begin{array}{l}\text { Frequent lessons of longer duration. } \\
\text { The number of contact hours is the } \\
\text { same as traditional course session. } \\
\text { In a compressed format. }\end{array}$ & $\begin{array}{l}\text { Frequent lessons of longer duration than in } \\
\text { the accelerated or traditional format. } \\
\text { Instructional time is further compressed } \\
\text { through effective instructional methods }\end{array}$ \\
\hline
\end{tabular}

For the purposes of this study, there is no further differentiation between accelerated and intensive courses, as the focus is on the compressed format, which is the same for both types of courses (Lutes and Davies 2018). Arrey (2005) further noted that the terms "accelerated courses" and "intensive courses" are sometimes used interchangeably.

Various intensive or time-shortened courses are offered by a South African university's Economics and Management Sciences faculty. These courses are referred to as summer or winter schools and are offered for regular semester or year modules. An example of these schools offered are for Business Management (semester module - 14 weeks) and Financial Accounting (year module - 27 weeks). All lectures are 50 minutes in duration. Notably these summer or winter schools are currently offered to students who fail a module and therefore are offered the accelerated learning format as an alternative to repeating the course on the traditional semester or year-module mode.

These schools are essentially an opportunity for students who failed a module to pass an accelerated and compressed version of the module. This is assessed by the same method as the module in an attempt to still pass the module so that the module does not have to be repeated the following year, thus improving the first-year throughput rate. All students completing the relevant modules are made aware of these schools at the commencement of the traditional module, they are therefore aware that the module will be offered using a traditional lectured 
module as well as an accelerated time-based school.

The objectives of this study are twofold: firstly, to understand first-year students' perceptions of the current semester module schools on offer at a South African university; and secondly, to understand first-year students' perceptions regarding a proposed summer school for a first year Financial Accounting module (a year module), as accelerated learning courses have been offered to them for both first and second semester modules.

Student perceptions were obtained by means of questionnaires at the end of the academic year, which provided qualitative and quantitative data. Given that various summer and winter schools occur through the academic year, performing the survey at the end of the academic year ensures that respondents are aware and familiar of the nature of accelerated courses in comparison to traditional higher education undergraduate modules. Qualitative data were obtained from open-ended questions. Quantitative data were obtained via Likert-scale questions in the questionnaire. Student perceptions were obtained from first-year Bachelor of Commerce students enrolled in Financial Accounting I at a South African university.

The next section of this article provides a review of existing relevant literature on the topic. The literature review is followed by an explanation of the research methodology, and a discussion of the findings and conclusions of the study.

\section{LITERATURE REVIEW}

Numerous studies indicate that due to the perceived negative impact on learning and decline of academic rigor (Martin and Culver 2009; Thornton, Demps, and Jadav 2017), faculties are still hesitant to move away from the traditional format and to offer courses in an intensive compressed format. A strong body of research exists that has evaluated the academic performance of students in compressed accelerated courses that vary in duration and class contact time in comparison with traditional course lengths (Anastasi 2007; Austin and Gustafson 2006; Eames, Luttman and Parker 2018), as well as students' perceptions of accelerated courses (Burton and Nesbit 2008; Herrmann and Berry 2016; Wlodkowski and Westover 1999).

Simonson's $(1999,7)$ equivalency theory indicates that "distance education's appropriate application should provide equivalent learning experiences for all students - distant and local - in order for there to be expectations of equivalent outcomes of educational experience". The equivalency theory was established by Simonson (1999) through Keegan's (1995) study, which indicated that courses taught online could create a virtual classroom by electronically linking instructors and students at various locations (Simonson 1999). Lapsley et al. (2008) results supported the existence of the equivalency theory. Although the equivalency theory is based on 
online and face-to-face course learning experiences being the same, this theory is relevant to this study, suggesting that the learning experience and performance of students enrolled in accelerated intensive course formats and traditional formats, should be equal, with content and teaching pedagogy remaining the same.

Ferguson and DeFelice (2010) used the equivalency theory to assess whether this theory held true for online courses of various lengths, namely five-week online courses compared to 15-week courses. The study focused on students' perceived differences of satisfaction, learning, and performance in online courses of various lengths. Vlachopoulos, Jan, and Lockyer (2019) conducted a similar study that assessed the effectiveness of achieving learning outcomes in a traditional (i.e., 13-week academic session) and intensive (i.e., six-week academic session) delivery format for online courses.

The second theory relevant to this study is the spacing effect, which suggests that "student learning will be enhanced by introducing/teaching course material in regular increments spread out over a longer time period" (Carrington 2010, 58). This study focused on students' perceptions of compressed courses in a summer/winter school format and did not assess student performance in various degrees of course length. The theory of the spacing effect is therefore relevant to a limited extent.

\section{STUDENT PERFORMANCE IN ACCELERATED COURSES IN COMPARISON WITH TRADITIONAL COURSES}

Prior literature indicates two main views on the performance of students in an accelerated course format compared to the traditional course format. The first view is that there is no significant difference between the performance of students who study in an accelerated format in comparison with the traditional format (Anastasi 2007; Austin and Gustafson 2006; Carrington 2010; Eames et al. 2018; Scyoc and Van Gleason 1993; Thornton et al. 2017) and concludes that course length has an impact on student performance, which indicates that performance improves for students who are enrolled in accelerated courses in comparison with their traditional-length counterparts. Possible reasons for improved performance in accelerated courses are (1) students having more out-of-class time to study, (2) limited lecturer contact time, which allows students to focus on work, (3) students in accelerated courses being more motivated than traditional students, and (4) students having a sense of urgency and managing their time better to learn the course material as a result of the compressed time format (Thornton et al. 2017). According to Thornton et al. (2017), these reasons are still subject to speculation.

Carrington (2010) studied the effects of spacing on Intermediate Accounting students by comparing student performance across four scheduling formats. A comparison of student 
performance across the following scheduling formats was performed: an intensive one-day-aweek session for 140 minutes, two 75-minute sessions per week, three 50-minute sessions per week, and a compressed four- to five-week summer session where students met daily for two hours. The one-, two-, and three-day sessions were held over a 15-week period. Carrington (2010) found that the students' performance did not depend on the course length format between the intensive one-day-a-week course, the compressed four- to five-week course, and the traditional two-days-per-week course. However, student performance in the three-days-a-week traditional format was significantly lower than the other course formats, which indicates that course sessions of three days a week for Intermediate Accounting are not suitable for students, which is contrary to the spacing effect.

Eames et al. (2018) found that alumni accounting students who studied in the accelerated course and the traditional accounting course took a similar number of attempts to pass the Certified Public Accountant (CPA) examination. There was no significant difference in terms of the number of attempts between students enrolled in the accelerated summer and winter programme, which respectively had four-hour daily sessions over 15 weeks, and two four-hour class sessions held either on a Saturday or Sunday over 10 weeks; in comparison with the traditional accounting course held over an 11-week quarter system (10 weeks of instruction, followed by one week of examinations).

Austin and Gustafson (2006) compared the performance of students across accelerated courses scheduled across three-, four-, and eight-week sessions with that of a traditional 16week semester course. Austin and Gustafson (2006) concluded that students who study in an intensive course format perform better and achieve higher grades than students who study in a traditional 16-week semester course. Austin and Gustafson (2006) further investigated the impact on student performance across the variations of compressed course lengths and identified that students' performance peaked at a course length of four weeks, where students receive the optimum learning benefit. Thornton et al. (2017), who compared the performance of students enrolled in an eight-week accelerated course with 24 contact hours with students enrolled in a traditional 15-week class that had approximately 40 contact hours, support Austin and Gustafson (2006) conclusions. The students' performance was evaluated through the assessment of the students' results in the Educational Testing Service (ETS) Major Field Test for the Bachelor's Degree in Business (MFTB), which is taken by students enrolled in both course formats. Scyoc and Van Gleason (1993) concluded that although compressed course length positively affects students' learning and test results, in comparison with traditional courses, there is no significant difference in knowledge retention between students who study microeconomics in three-week or 14-week sessions. 
Studies that assessed students' performance in compressed course lengths and traditional course formats kept various factors (e.g., instructors, course content, learning material, assignments, class activities, and assessments) relatively constant. Minor reductions and changes to course content and reduction in the number of assignments and readings, quizzes, and examinations are done by instructors to accommodate the limited time in the timecompressed format, thus resulting in a lighter workload compared to semester course counterparts, which results in students spending fewer hours out of class than required (Lutes and Davies 2018).

The purpose of this study was to assess students' perceptions of an accelerated first-year Financial Accounting year course and students' perceptions of courses in an accelerated format in general. The proposed accelerated course is eight days long, with two four-hour sessions per day, as compared with the traditional year module, which is 27 weeks long. Most previous studies have assessed students' performance in accelerated courses of various lengths to traditional courses not longer than a semester (16 to 17 weeks) (Anastasi 2007; Austin and Gustafson 2006; Carrington 2010; Caskey 1994). Although Eames et al. (2018) compared the performance of students enrolled in an accelerated summer programme with the traditional accounting programme held on the quarter system, the students' performance was assessed based on the number of attempts to pass their CPA examination, after graduating from university, and did not focus on the performance of undergraduate students enrolled in accelerated and traditional courses.

\section{STUDENT PERCEPTIONS}

A review of the existing literature suggests that the focus on accelerated course learning has been on more mature adult students. Adult students are defined as students older than 22 years at the time of university enrolment (Richardson and King 1998). Existing literature suggests that these students enrolled in accelerated course formats indicated a high level of satisfaction with the content and presentation of the accelerated courses (Richardson and King 1998; Wlodkowski and Westover 1999; Herrmann and Berry 2016). This study therefore contributes to the literature by focusing on first time entrants into a university through examining first year student perceptions at the end of their first academic year.

Wlodkowski and Westover (1999) studied the course satisfaction and learning levels of both adult and alumni students from 5 week accelerated courses to traditional students enrolled in 16-week courses. Student participants were enrolled across six subjects (Accounting II, Business Law, Corporate Finance, Introduction to Philosophy, Management, and Management of Human Resources). Adult and alumni student feedback indicated that students' perceptions 
of motivational conditions, instructions, and learning materials being used were generally positive and that the students were satisfied with their accelerated course experience. Overall, this indicates positive and similar satisfaction levels with the course compared to traditional students enrolled in a 16-week course of the same subject. Herrmann and Berry (2016) performed a study on the perceptions of students enrolled in accelerated master's in business administration courses, where student feedback was similarly positive and indicated that the students felt they learned the same or more compared to traditional course formats.

Students' preference for accelerated courses compared to traditional-length courses is driven by their ability to better schedule their courses, time management, less boredom and burnout, increased peer interaction, increased retention of learning material, and better learning experiences (Herrmann and Berry 2016). Their preference for accelerated courses is also driven by their desire to complete a course faster (Herrmann and Berry 2016) and graduate on time, to lighten the semester workload, and to meet prerequisites (Wayland 2000). Burton and Nesbit (2008) identified that students' prior experience with the intensive format, current subject workload, and perception of their ability in a particular subject will further influence their decision to study in this course format.

It is noteworthy that students have a slightly lower preference for quantitative subjects in an accelerated format as compared to qualitative subjects (Herrmann and Berry 2016). Burton and Nesbit (2008) noted that students who had prior experience with learning in an accelerated format remained hesitant to enrol in an accounting course in an intensive format, which indicates a decrease in preference for quantitative subjects in this format. Burton and Nesbit (2008) suggested that the rationale for this is that students are generally nervous about their abilities to manage learning material for accounting (and perhaps other quantitative subjects) in an intensive format.

Wayland (2000), however, found that students in an accelerated course had a less positive course experience. The majority of students in three- and four-week sessions felt that more time had to be invested in studies for the accelerated course, which was contradictory to their initial expectations of the accelerated course (lighter workload, and less commitment in terms of studies and time), thus resulting in lower grades (Wayland 2000). Lutes and Davies (2013), however, concluded that students spent 17 more minutes per credit per week on regular semester courses (16 weeks) as compared to eight-week compressed courses, which indicates that students spent less out-of-class time per credit on accelerated courses than their traditional counterparts.

In most bodies of research, students who took accelerated courses tended to be older than students in the traditional course formats. These courses particularly focused on meeting adult 
students' educational needs (Caskey 1994; Wlodkowski and Westover 1999) or working students' needs (Wayland 2000). The sample of students in Caskey's (1994) study indicated that there was an age variance between students enrolled in the traditional course format and the accelerated course format for accounting and algebra, with students in the accelerated courses tending to be older.

For the purposes of this study, students' perceptions of accelerated courses were studied among first-year students enrolled in a Financial Accounting year module at a South African university. The majority of these students were traditional students who were first-time entrants in university and who recently matriculated through the South African education system, and thus have little or no experience in accelerated courses in comparison with prior studies of adult students' perceptions.

\section{RESEARCH METHODOLOGY}

\section{Research objective}

The objectives of this study are twofold: firstly, to understand first-year students' perceptions of the current semester schools on offer at a South African university; and secondly, to understand first-year students' perceptions regarding a proposed summer school for Financial Accounting (a year module), as accelerated learning courses have been offered to them for both first and second semester modules.

\section{Methodology}

The research sample was constituted from the 2019 first year students enrolled in the Financial Accounting 188 year module. These students have further enrolled for other semester modules that offer summer and winter schools. The timing of the survey, namely at the end of the academic year allows students to familiarise themselves with the nature and scope of summer and winter schools as various schools are offered during the half year recess and before the commencement of the 2020 academic year. Ethical considerations regarding the use of first year students and obtaining student perceptions was done as part of the university's ethical review process.

Student perceptions of accelerated short courses of longer semester and year modules was done through obtaining both qualitative and quantitative data through an electronic questionnaire presented to first-year Financial Accounting students at a South African university. The questionnaire, as shown in Appendix 1, included various statements that students had to respond to using a five-point Likert scale, either agreeing or disagreeing with 
the statement $(1=$ strongly disagree; $5=$ strongly agree $)$. A total of 34 respondents who were first-year students enrolled at a South African university replied to the questionnaire.

Descriptive analysis was performed on the responses to the questionnaire. Furthermore, a few open-ended questions were included, and these responses were analysed via simple narrative content analysis.

The analysis of the results of the questionnaire is discussed under the following categories:

1. Students' general perceptions of attending a summer/winter school.

2. Students' perceptions of their current course workload, assessment preparation, and scheduling preferences.

3. Students' perceptions of their expectations of the introduction of additional summer/winter school modules; and

4. Additional considerations regarding students' perceptions of a summer/winter school.

\section{FINDINGS}

The following section discusses the findings that resulted from the various perceptions obtained. The section starts with a descriptive analysis of the questionnaire respondents and narrative content analysis pertaining to the open-ended questions.

\section{Descriptive analysis}

\section{Students' general perceptions of attending a summer/winter school}

Table 2 shows the results of the students' general perceptions of the rationale for attending summer/winter schools and possible perceived factors that may result in students enrolling in a summer/winter school.

Table 2: Students' general perceptions of attending a summer/winter school

\begin{tabular}{|l|c|c|}
\hline \multicolumn{1}{|c|}{ Statement } & N & Mean \\
\hline $\begin{array}{l}\text { Modules that have summer/winter schools allow students to focus less on the final } \\
\text { assessments (A2/A3) as there is another opportunity for these students to pass. }\end{array}$ & 32 & 3.333 \\
\hline $\begin{array}{l}\text { The reason why the majority of students make use of summer/winter schools is as a } \\
\text { result of poor time management. }\end{array}$ & 30 & 3.333 \\
\hline $\begin{array}{l}\text { The reason why the majority of students make use of summer/winter schools is due } \\
\text { to the underestimation of their current workload. }\end{array}$ & 32 & 3.875 \\
\hline $\begin{array}{l}\text { The reason why the majority of students make use of summer/winter schools is that } \\
\text { they have spent most of their time focusing on passing other modules that do not } \\
\text { have such schools. }\end{array}$ & 33 & 3.242 \\
\hline
\end{tabular}


The results show that most students would make use of summer/winter schools due to the underestimation of their current workload (mean $=3.875)$. Additional factors such as poor time management $($ mean $=3.333$ ) and students spending more time focusing on passing other modules that do not have summer/winter schools (mean $=3.242)$ contributed towards students repeating a module to a lesser extent. It is noteworthy that the students indicated that they spent a similar amount of time for A2/A3 assessment preparations for all modules, irrespective of whether the module offered a summer/winter school should the student fail. The students' responses leaned more towards the neutral side (mean $=3.333$ ), which suggests that students preferred to pass within the normal course of the year, and not repeat a module that would incur additional costs. More so, summer/winter schools result in repeating classes and assessments in an intensive compressed format, which occur during the student vacation period.

\section{Students' perceptions of their current course workload, assessment preparation, and scheduling preferences}

Table 3 shows the results of the students' perceptions regarding the out-of-class time spent on studying their current course. Furthermore, Table 3 shows the results of students' perceptions of the amount of time they spend on preparation for assessments and preferred assessment scheduling.

Table 3: Students' perceptions of their current course workload, assessment preparation, and scheduling preferences

\begin{tabular}{|l|c|c|}
\hline \multicolumn{1}{|c|}{ Statement } & N & Mean \\
\hline $\begin{array}{l}\text { I spend less study time and do not focus as much on modules that are year } \\
\text { modules and not my majors, in comparison with modules that are my } \\
\text { electives. }\end{array}$ & 32 & 2.531 \\
\hline $\begin{array}{l}\text { For final assessments (A2/A3), I only study for the module in the free period } \\
\text { between my previous assessments and prior to the A2/A3 assessment. }\end{array}$ & 32 & 2.469 \\
\hline $\begin{array}{l}\text { I would prefer the exam timetable to be more spread out so that I can } \\
\text { allocate my study time appropriately to all my modules in order to pass. }\end{array}$ & 31 & 3.968 \\
\hline
\end{tabular}

Based on the results, the authors found that students do not appear to spend less study time or focus less on modules that are not their majors in comparison to their electives (mean $=2.469$ ). This suggests that students spend an appropriate amount of time on all their respective modules in order to pass and proceed to the subsequent year, and not favour modules that are their electives in comparison to supplementary modules they are enrolled in. More so, the findings indicate that students appropriately manage their study time between the A2 and A3 assessments for the respective modules (mean $=2.469$ ), which further supports the students' motivation to pass all modules through adequate time management. 
The results also show that students would prefer that assessments are more spread out so that their study time could be allocated appropriately between modules $($ mean $=3.968)$. This suggests that students may have a challenge with time management, which further puts pressure on students when balancing their study time between the A2 and A3 assessments.

\section{Students' perceptions of their expectations and the introduction of additional summer/winter school modules}

Table 4 presents the results of the students' perceptions of their expectations of a summer/winter school module in respect of module design and curriculum, as well as students' perceived learning opportunities related to attending these schools. In addition, Table 4 presents the students' perceptions of their willingness to enrol in a summer/winter school in order to prevent repeating a module and their recommendation for a summer school for a first-year Financial Accounting year module.

Table 4: Students' perceptions of their expectations and introduction of additional summer/winter school modules

\begin{tabular}{|c|c|c|}
\hline Statement & $\mathbf{N}$ & Mean \\
\hline $\begin{array}{l}\text { Students who complete either a summer/winter school will be more } \\
\text { prepared for the module for which they attended a summer/winter } \\
\text { school in the next semester/following year. }\end{array}$ & 33 & 3.818 \\
\hline $\begin{array}{l}\text { Summer/winter schools should be timed in such a way that a } \\
\text { student can attend various subjects' summer/winter schools. }\end{array}$ & 31 & 3.548 \\
\hline $\begin{array}{l}\text { Enrolling and passing a summer/winter school will be more } \\
\text { challenging in comparison with the semester module, as the } \\
\text { module will be covered in a short span of time. }\end{array}$ & 31 & 2.29 \\
\hline $\begin{array}{l}\text { Instead of a summer/winter school, there should rather be an extra } \\
\text { revision class(es) prior to A3. }\end{array}$ & 34 & 2.412 \\
\hline $\begin{array}{l}\text { Summer/winter schools should be available for modules that are } \\
\text { not students' elective modules and are only a prerequisite for the } \\
\text { first year, in order to give students an opportunity to pass the } \\
\text { module instead of repeating the module in the following year. }\end{array}$ & 28 & 4.179 \\
\hline $\begin{array}{l}\text { Summer/winter schools for a module should cover the same } \\
\text { content as the actual module and not only focus on key or high-risk } \\
\text { chapters. }\end{array}$ & 31 & 2.71 \\
\hline $\begin{array}{l}\text { I am willing to pay the entire module fee for a summer/winter school } \\
\text { that I have to attend in order for me to pass the module and not } \\
\text { repeat the module in the following year. }\end{array}$ & 30 & 3.733 \\
\hline $\begin{array}{l}\text { I am willing to pay the entire module fee for a summer/winter } \\
\text { school; however, I will have difficulties acquiring the funds and will } \\
\text { require financial assistance in order to attend and pass the } \\
\text { summer/winter school and not repeat the module in the following } \\
\text { year. }\end{array}$ & 30 & 3.7 \\
\hline $\begin{array}{l}\text { I would recommend the establishment of a summer school for } \\
\text { Financial Accounting } 188 \text {. }\end{array}$ & 26 & 3.846 \\
\hline \multicolumn{3}{|l|}{ Have you previously completed a summer/winter school? } \\
\hline & $\mathbf{N}$ & Percentage \\
\hline Yes & 12 & 35 \\
\hline No & 21 & 62 \\
\hline Prefer not to say & 1 & 3 \\
\hline Total & 34 & 100 \\
\hline
\end{tabular}


The authors found that the students were interested in attending summer/winter schools should they be required to do so in order not to repeat a module. The findings show that students were willing to pay the fees associated with summer/winter schools (mean $=3.733$ ); however, these same students may require additional financial assistance in order to enrol in these schools $($ mean $=3.7)$. Further student responses identified this financial constraint when enrolling in such schools. One suggestion by students is offering a reduced fee or discount for such schools, as indicated by student comments such as "a discount instead of paying the full amount for the module (10-15\% disc.)" and "the summer/winter schools should be at a discounted value". This suggests that students may not be able to afford enrolling in numerous summer/winter schools, which suggests that the fee structure and feasibility of students being able to afford these schools should be established before implementing summer/winter schools for a broad array of modules.

The students' feedback shows that a summer/winter school would provide students with an additional opportunity to pass the module and not repeat a module in the following year, which further motivates them. One student who previously attended a winter school commented:

"Students who prepared during the year will most likely pass and they deserve such a chance. When I did winter school, I was ready to pass, and I did just that. It was so easy."

Another student commented:

"I think it is an amazing opportunity for students to pass modules that they do not really want to focus on, because first year can be hard for a lot of students. So, having something like a summer school is like having another chance to pass a module as fast as possible so that you can get to what you as a student really want to do and focus on."

The students' willingness to enrol in a summer/winter school suggests that the associated costs of repeating a module are consistent with Wayland's (2000) findings, who suggested that one of the reasons that students enrolled in accelerated summer programmes is as a result of not passing a module previously and wishing to decrease the subsequent semester's workload.

Based on the results, summer/winter schools should be offered to all first-year modules (mean $=4.179)$. In support of this finding, the results show that students would prefer that these schools be timed in a way that students can attend more than one subject's summer/winter school (mean $=3.548)$. These findings suggest that there is a need for such schools as students may not be passing their respective modules. Even though various interventions are offered for 
first-year modules, such as mentoring, tutoring, and additional classes, it appears that further non-academic obstacles contribute to students being unable to pass a module, and not solely poor academic performance factors such as insufficient time spent on studying, as suggested by Johnston (1997), Petersen et al. (2009), and Naidoo and McKay (2018). The schools can therefore possibly provide students with an opportunity to complete the same module in an environment with fewer non-academic obstacles, which in turn may result in improved throughput rates in terms of increased student success.

The results also show that the students would recommend the establishment of a summer school for the first-year Financial Accounting module at a South African university $($ mean $=3.846)$. This suggests that students are indifferent to whether a summer/winter school is provided for a semester or year module or whether the module is a quantitative subject, which is contrary to Burton and Nesbit's (2008) findings. The results show that the students did not consider summer/winter schools as more challenging than their traditional semester module counterparts as a result of the time-compressed format (mean $=2.29$ ); however, the majority of the respondents had not had any experience of summer/winter schools (mean $=62 \%$ ), which could possibly skew students' perceptions. According to Burton and Nesbit (2008), students' prior experience with the accelerated block format is a factor that may influence their preference for this format.

Contrary to the students' positive perceptions of summer/winter schools and not identifying these schools as more challenging, the students identified perceived challenges to the establishment of a summer school for a year module (such as Financial Accounting 188). The students identified potential challenges to studying a year's worth of content in a compressed format, such as that "there is a lot of work to cover in a short period of time" and "revising a whole year work in two weeks". One student commented that "there is a lot of work to cover - the question you ask, is that short period of time [summer school] actually enough to retain such important information?", which questions whether it is feasible for students to pass summer school. This suggests a perception that students who attend these schools may be those who may not have grasped the learning outcomes and principles for the module during the year. This was further evidenced by the following illustrative comments:

\footnotetext{
"Students will come in knowing nothing, as they failed a year module with multiple assessment opportunities and regular tutorial classes."

"It's a lot more work so the pace will be insane but really if you didn't understand the work in class then you are very less likely to pass the module because you don't have time to grasp context; it's pretty much learning how to answer and fixing a few other mistakes. So, the challenge would be having to learn a lot in a very short time space."
} 
"Not grasping the full concept and moving to the next year with insufficient knowledge."

To reduce the high work volume and pressure of fitting in a year's worth of work for first-year Financial Accounting, in an accelerated format, one student suggested that "it should be recommended to students who want to partake in summer school to prepare the work before the actual summer school". This suggests that lecturers could consider introducing course preparatory work prior the commencement of the summer school when developing the course design. Some students may prefer to learn at a "fast pace", as indicated by another student.

One student had no concerns regarding the proposed summer school and provided the following comment:

"None really. I work full time and summer schools truly assist in me understanding principles over the long term while intensely focusing on one subject, whereas the scattered subjects from my course causes disarray and we cannot link the purpose of the subject with the course. So, the fact that winter/summer school is there is a good idea."

The students' interest in summer/winter schools is further indicated by the results that show that the students perceived that completing a summer/winter school would improve their preparedness for the subsequent intermediate module for which they would attend a summer/winter school (mean $=3.818)$. This suggests that students who attend summer/winter schools in order to pass a module additionally perceive the summer/winter school as revision and as an opportunity to build a foundation for the first-year introductory module, which may assist with students performing better and passing in the second-year module. This is particularly relevant to students who may have struggled with grasping various concepts during the year, pertaining to the respective module before continuing with the proceeding module. The students' learning perceptions are consistent with prior studies (Austin and Gustafson 2006; Thornton et al. 2017), which concluded that students who learn in an accelerated course format perform better than students who learn in the traditional format. The findings further support Ferguson and DeFelice (2010)'s study on the equivalency theory, which states that perceived learning benefits are similar for students in traditional and accelerated course formats.

In addition, the students preferred a summer/winter school instead of additional revision classes prior to A3 for a respective module. For the context of this statement, A3 pertains to the third assessment opportunity offered to students who failed to obtain a final mark of 50 per cent for the respective module, as per the module framework. This suggests that the students preferred an additional learning and assessment opportunity over and above the third assessment opportunity - should they have failed this due to numerous factors. 
The findings indicate that the students' perceptions lean more towards summer/winter schools for a module with the focus on key or high-risk chapters and not all module content (mean $=2.71)$. This suggests that the students would prefer a summer/winter school course design that focuses on key or high-risk chapters as a minimum, considering the time constraints of an accelerated course. More so, the objective of a summer/winter school is to provide students with another opportunity to pass a module and to not repeat a module in the following year, thus justifying lecturers to focus on topics that students generally struggle with.

The findings suggest that the students had a positive perception of the introduction of a summer school for a first-year Financial Accounting year module, as well as non-elective subjects. The motivating factor for students is not repeating the module in the following year and thus reducing the second-year workload. The summer/winter school opportunity provides students with another chance apart from the supplementary assessment to try to pass. More so, the summer/winter school opportunity offers classes in a similar format to the traditional format, which are smaller and thus less intimidating and supportive due to, according to the response of one student, "the one-on-one with the lecturers, and you don't feel stupid for asking a question".

Table 5 presents the results of the students' perceptions of the expectations of the module design for a summer/winter school.

Table 5: Students' perceptions of the expectations of the module design for a summer/winter school

\begin{tabular}{|c|c|c|}
\hline Statement & $\mathbf{N}$ & Percentage \\
\hline $\begin{array}{l}\text { What would you like summer/winter schoo } \\
\text { For example: } \\
\text { - Theory } \\
\text { - Exam technique } \\
\text { - Question class and tutorials } \\
\text { - All of the above }\end{array}$ & & \\
\hline All of the above & 21 & 62 \\
\hline Combination of learning focus areas & 13 & 38 \\
\hline Total & 34 & 100 \\
\hline
\end{tabular}

The findings show that students would prefer the summer/winter school to be in the same format as the traditional lecture, which consists of theory, examination technique, question class, and tutorials (mean $=62 \%$ ), which further supports the equivalency theory that states that course learning experiences should be the same regardless of the learning format. The remaining students preferred various combinations of the focus learning areas, but not all of them.

\section{CONCLUSION}

This study found that students have a positive sentiment towards summer/winter schools and 
support the establishment thereof. Although not all respondents attended an accelerated course, the timing of the questionnaire at the end of the academic year allows students to be aware of the nature and format of accelerated short courses as various such schools are available to them throughout their first academic year. Students were indifferent to a proposed summer/winter school for a semester module and a year module, or a quantitative subject such as first-year Financial Accounting at a South African university, as indicated by the students' recommendations for such a school. From the perspective of the students, the main rationale for their positive response is to prevent students repeating a module and to reduce their secondyear workload. It is evident that the cost of repeating a module has financial and social implications.

The cost of repeating a module suggests that summer/winter schools should be offered for all modules and not only a select few, as indicated by student perceptions. Careful consideration of the feasibility thereof will need to be assessed, considering available university resources, staff capacity, timetable constraints, as well as the affordability of these courses. Further findings suggest that students may have difficulty acquiring funds and may require financial assistance, in addition to the above constraints. This brings to light the funding challenges students currently face and the increased cost of higher education.

When assessing the factors that contribute to first-year student failure, the students appear to adequately manage their time and workload for both elective and non-elective modules, and do not favour one over the other in respect of study time. A limitation to the current study is that not all potential factors for failing a module were considered. Students prefer the examination timetable to be more spread out in order to allocate appropriate study time between modules. This suggests that students may lack important time management skills in order to be successful in their studies; more so in adjusting to the large volume of work at university, as opposed to the schooling curriculum, as well as additional non-academic factors that may contribute negatively to student success.

This study found that summer/winter schools may have ongoing learning benefits, contributing to perceived struggling students to build a foundation for the respective intermediate module, as the students perceived that summer/winter schools assist them in being more prepared for intermediate modules. Furthermore, summer/winter schools could be introduced by the faculty as a refresher course before the introduction of an intermediate module, thus further potentially contributing to the success of second-year students. Time constraint challenges to studying Financial Accounting, a year module in an accelerated format, were identified by the students, particularly for students who may not have grasped the content during the year and thus have a further challenge of managing the workload during summer 
school, in addition to understanding the content in order to pass the module.

Overall, there is a perceived benefit by the students of summer school attendance, which suggests that the students' learning opportunities should be equivalent for the accelerated summer school to the traditional semester or year module, as indicated by the equivalency theory with regard to the learning experiences of traditional and distant courses being equivalent.

This study focused on students' perceptions of summer/winter schools for the first year, with the majority of the students lacking experience in the accelerated content format. Furthermore, the subsequent performance and pass rate of students who attended summer/winter schools were not assessed, which presents a further area for future research.

This research contributes to the understanding of the perceptions of first-year students of various summer/winter schools in accelerated or compressed module format and the rationale for attending these schools, which has been found to be a limited area in the existing literature which focus on mature students and accelerated courses.

The establishment of these schools could assist students in reducing the high costs associated with repeating a module over an academic year, thus changing the faculty's perceptions of the recommendation of developing such schools and, to a lesser extent, improving throughput rates for first-year students and increasing first-year university capacity.

\section{REFERENCES}

Africa Check. 2016. "FACTSHEET: Funding and the changing face of South Africa's public universities | Africa Check." Africa Check. https://africacheck.org/factsheets/factsheet-fundingchanging-face-sas-public-universities/ (Accessed 25 February 2020).

Anastasi, J. S. 2007. "Full-Semester and Abbreviated Summer Courses: An Evaluation of Student Performance." Teaching of Psycology 34(1): 19-22.

Arrey, L. N. 2005. "Intensive learning versus traditional learning in organic chemistry." Summer Academe 5(1): 21-26.

Austin, A. M. and L. Gustafson. 2006. "Impact of Course Length on Student Learning." Journal of Economics and Finance Education 5(1): 21-37.

Baard, R. S., L. P. Steenkamp, B. L. Frick and M. Kidd. 2010. "Factors influencing success in first-year Accounting at a South African university: The profile of a successful first-year Accounting student." South African Journal of Accounting Research 24(1): 129-147.

Blöndal, S., S. Field, and N. Girouard. 2002. "Investment in human capital through upper-secondary and tertiary education." OECD Economic Studies 2002(1): 41-89.

Business Tech. 2018. "Government changes minimum entry requirements for a Bachelor's degree in South Africa." BusinessTech. https://businesstech.co.za/news/government/288442/governmentchanges-minimum-entry-requirements-for-a-bachelors-degree-in-south-africa/ (Accessed 25 February 2020).

Business Tech. 2019. "2018 Matric pass rate climbs to 78.2\%." BusinessTech. https://businesstech.co.za/news/government/292166/2018-matric-pass-rate-climbs-to-78-2/

(Accessed 25 February 2020). 
Burton, S. and P. L. Nesbit. 2008. "Block or traditional ? An analysis of student choice of teaching format." Journal of Management and Organization 14(1): 4-9.

Carrington, L. G. 2010. "The impact of course scheduling on student success in Intermediate Accounting." American Journal of Business Education 3(4): 51-60.

Caskey, S. R. 1994. "Learning outcomes in intensive courses." The Journal of Continuing Higher Education 42(2): 23-27.

Centre for Chinese Studies. 2014. Conference: Building infrastructure and capacity in higher education: Lessons from China and South Africa. Stellenbosch University. http://www0.sun.ac.za/ccs/?p=10413 (Accessed 25 February 2020).

De Jager, E. and R. S. Baard. 2019. "Does 'free' higher education in South Africa make economic sense?" South African Journal of Higher Education 33(6): 70-91.

Department of Basic Education. 2019. "Subject choice and career pathing." Department of Basic Education. https://www.education.gov.za/Informationfor/Learners/SubjectChoiceandCareer Pathing/tabid/980/Default.aspx (Accessed 25 February 2020).

Eames, M., S. Luttman, and S. Parker. 2018. "Accelerated vs. traditional accounting education and CPA exam." Journal of Accounting Education 44: 1-13.

Edgecombe, N. 2011. "Accelerating the academic achievement of students referred to developmental education." Assessment of Evidence Series.

Etheridge, J. 2020. "Matric 2019 results by numbers and provinces." News24. https://www.news24.com/SouthAfrica/News/matric-2019-results-by-numbers-and-provinces20200108 1/6 (Accessed 25 February 2020).

Ferguson, J. M. and A. E. Defelice. 2010. "Length of online course and student satisfaction, perceived learning, and academic performance." The International Review of Research in Open and Distributed Learning 11(2): 73-84.

Government Gazette. 2018. Higher Education Act, 1997 (Act No.101 of 1997) Notice of amendment of minimum admision requirements for Higher certificate, Diploma and Degree programmes requiring a National Certificate (Vocational) at Level 4 of National Qualifications Framework.

Herrmann. M. and K. Berry. 2016. "An investigation into graduate student preference for compressed courses." Academy of Educational Leadership Journal 20(2): 23-33.

Hesterman, D. 2015. Intensive mode delivery of courses in Engineering, Computer Science and Mathematics. Faculty of Engineering, Computing and Mathematics: The University of Western Australia.

Hyun, E., M. Kretovics, and A. Crowe. 2006. "Curriculum characteristics of time-compressed course in a U.S. higher education institution.” Educational Research and Review 1(2): 29-39.

Johnston, V. 1997. "Why do first year students fail to progress to their second year? An academic staff perspective." Paper presented at the British Educational Research Association Annual Conference, York University, 11-14 September.

Keegan, D. 1995. Distance education technology for the new millennium: Compressed video teaching. (ZIFF papiere). Hagen: Institute for Research into Distance Education.

Lapsley, R., B. Kulik, R. Moody, and J. B. Arbaugh. 2008. "Is Identical really identical? An investigation of Equivalency theory and online learning." The Journal of Educators Online 5(1): $1-19$.

Lutes, L. and R. Davies. 2013. "Comparing the rigor of compressed format courses to their regular semester counterparts." Innovative Higher Education 38(1): 19-29.

Lutes, L. and R. Davies. 2018. "Comparison of workload for university core courses taught in regular semester and time-compressed term formats." Education Sciences 8(12): 1-12.

MacGregor, K. 2014. "The massification of higher education in South Africa." University World News. www.universityworldnews.com/article.php?story=2014062015083621 (Accessed 25 February 2020). 
Macupe, B. 2019. "Nzimande wants to prioritise rural universities." Mail and Guardian. https://mg.co.za/article/2019-09-28-00-nzimande-wants-to-prioritise-rural-universities (Accessed 26 February 2020).

Marriah, J. and S. Mlambo. 2020. "Motshekga all smiles as matric Class of 2019 breaks $80 \%$ pass rate." IOL. https://www.iol.co.za/news/south-africa/motshekga-all-smiles-as-matric-class-of-2019breaks-80-pass-rate-barrier-40218224 (Accessed 25 February 2020).

Martin, H. and K. B. Culver. 2009. "To concentrate, to intensify, or to shorten?" Summer Academe 6: 59-69.

Mohamedbhai, G. 2014. "Massification in higher education institutions in Africa: Causes, consequences and responses." International Journal of African Higher Education 1(1).

Muller, S. 2017. "Options on the table as South Africa wrestles with funding higher education." The Conservation. https://theconversation.com/options-on-the-table-as-south-africa-wrestles-withfunding-higher-education-87688 (Accessed 26 February 2020).

Muller, S. M. 2018. "Free higher education in South Africa: Cutting through the lies and statistics." The Conversation. https://mg.co.za/article/2018-01-25-free-higher-education-in-south-africa-cuttingthrough-the-lies-and-statistics/ (Accessed 26 February 2020).

Naidoo, A. and T. J. M. McKay. 2018. "Student funding and student success: A case study of a South African university." South African Journal of Higher Education 32(5): 158-172.

Petersen, I. H., J. Louw, and K. Dumont. 2009. "Adjustment to university and academic performance among disadvantaged students in South Africa." Educational Psychology 29(1): 99-115.

Prior, B. 2019. "South Africa's latest matric pass rate shock." Mybroadband. https://mybroadband.co.za/news/government/290732-south-africas-matric-pass-rate-1995-to2018.html (Accessed 26 February 2020).

PwC. 2015. "Funding of public higher education institutions in South Africa." $P w C$. https://www.pwc.co.za/en/publications/funding-public-higher-education-institutions-sa.html (Accessed 26 February 2020).

Richardson, J. T. E. and E. King. 1998. “Adult students in Higher Education: Burden or boon?" The Journal of Higher Education 69(1): 65-88.

Scott, P. A. and C. F. Conrad. 1992. "A critique of intensive courses and an agenda for research." Higher Education: Handbook of Theory and Research (8): 411-459.

Scyoc, L. J. and J. Van Gleason. 1993. "Traditional or intensive course lengths? A comparison of outcomes in Economics Learning." The Journal of Economic Education 24(1): 15-22.

Seeth, A. 2017. "Limited Space: Universities face thousands of first year queries." City Press. https://city-press.news24.com/News/limited-space-universities-face-thousands-of-first-yearqueries-20170111 (Accessed 26 February 2020).

Serdyukov, P. 2008. "Accelerated learning: What is it." Journal of Research in Innovative Teaching 1(1): 35-59.

Shrivastava, M. and S. Shrivastava. 2014. "Political economy of higher education: Comparing South Africa to trends in the world." Higher Education 67: 809-822.

The Skills Portal. 2017. "Overcrowded universities not the only learning option." The Skills Portal. https://www.skillsportal.co.za/content/overcrowded-universities-not-onlylearning-option (Accessed 26 February 2020).

Simonson, M. 1999. "Equivalency theory and distance education." TechTrends 43(5): 5-8.

Spaull, N. 2019. "Increase in 2018 matric bachelor's passes means universities headed for a perfect storm." Daily Maverick. https://www.dailymaverick.co.za/article/2019-01-07-increase-in-2018matric-bachelors-passes-means-universities-headed-for-a-perfect-storm/ (Accessed 26 February 2020).

Statistics South Africa. 2017. "Higher education and skills in South Africa." Education Series Volume $V$. 
Statistics South Africa. 2018. "Higher education continues to cut capital spending." Stats SA. http://www.statssa.gov.za/?p=11361 (Accessed 26 February 2020).

Stead, D. 2019. "How much does it cost to study a first year at a South African university." Go Study. https://www.gostudy.net/career-guidance/cost-of-university-study-in-south-africa (Accessed 26 February 2020).

Thornton, B., J. Demps, and A. Jadav. 2017. "Reduced contact hour accelerated courses and student learning." Journal of Instructional Pedagogies 18: 1-8.

Tjønneland, E. N. 2017. "Crisis at South Africa' s universities - what are the implications for future cooperation with Norway?" CMI. https://www.cmi.no/publications/6180-crisis-at-south-africasuniversities-what-are-the (Accessed 26 February 2020).

Vlachopoulos, P., S. K. Jan, and L. Lockyer. 2019. "A comparative study on the traditional and intensive delivery of an online course: Design and facilitation recommendations." Research in Learning Technology 27: 1-13.

Wangenge-Ouma, G. and N. Cloete. 2008. "Financing higher education in South Africa: Public funding, non-government revenue and tuition fees." South African Journal of Higher Education 22(4): 906-919.

Wayland, J. P. 2000. "Summer scheduling on a traditional campus: Expectations, reality, and implictaions." In Annual Conference of the Southwestern Marketing Association.

Wlodkowski, R. J. and T. N. Westover. 1999. "Accelerated courses as a learning format for adults." Canadian Journal for the Study of Adult Education 13(1): 1-20.

Xala, N. 2019. "Deputy Minister of Higher Education says overcrowding may lead to Universities deteriorating." Hypertext. https://www.htxt.co.za/2019/01/30/deputy-minister-of-highereducation-says-overcrowding-may-lead-to-universities-deteriorating (Accessed 26 February 2020). 


\section{APPENDIX 1:}

\section{Questions:}

Indicate to what extent you agree with the following statements. $(1) \rightarrow$ Strongly disagree and $(5) \rightarrow$ Strongly agree:

\begin{tabular}{|c|c|c|c|c|c|c|}
\hline & Statements & $\begin{array}{c}1 \\
\text { Strongly } \\
\text { disagree }\end{array}$ & 2 & 3 & 4 & $\begin{array}{c}5 \\
\text { Strongly } \\
\text { agree } \\
\end{array}$ \\
\hline & General perceptions of summer/winter school: & & & & & \\
\hline 1 & $\begin{array}{l}\text { Students who complete either a summer/winter school will be more prepared for the module for which they } \\
\text { attended a summer/winter school in the next semester/following year. }\end{array}$ & & & & & \\
\hline 2 & $\begin{array}{l}\text { Modules that have summer/winter schools allow students to focus less on the A2/A3 assessments as there is } \\
\text { another opportunity for these students to pass. }\end{array}$ & & & & & \\
\hline 3 & $\begin{array}{l}\text { The reason why the majority of students make use of summer/winter schools is as a result of poor time } \\
\text { management. }\end{array}$ & & & & & \\
\hline 4 & $\begin{array}{l}\text { The reason why the majority of students make use of summer/winter schools is due to the underestimation of } \\
\text { their current workload. }\end{array}$ & & & & & \\
\hline 5 & $\begin{array}{l}\text { The reason why the majority of students make use of summer/winter schools is that they have spent most of } \\
\text { their time focusing on passing other modules that do not have such schools. }\end{array}$ & & & & & \\
\hline 6 & $\begin{array}{l}\text { Summer/winter schools should be timed in such a way that a student can attend various subjects' } \\
\text { summer/winter schools. }\end{array}$ & & & & & \\
\hline \multirow[t]{2}{*}{7} & $\begin{array}{l}\text { Enrolling and passing a summer/winter school will be more challenging in comparison to the semester module, } \\
\text { as the module will be covered in a short span of time. }\end{array}$ & & & & & \\
\hline & Perceptions of the Financial Accounting 188 module and assessment process: & & & & & \\
\hline 8 & $\begin{array}{l}\text { I spend less study time and do not focus as much on modules that are year modules and not my majors, in } \\
\text { comparison to modules that are my electives. }\end{array}$ & & & & & \\
\hline 9 & $\begin{array}{l}\text { For A2/A3, I only study for the module in the free period between my previous assessments and prior to the } \\
\text { A2/A3 assessment. }\end{array}$ & & & & & \\
\hline 10 & $\begin{array}{l}\text { Instead of a summer/winter school, there should rather be an extra revision } \\
\text { class(es) prior to } \mathrm{A} 3 \text {. }\end{array}$ & & & & & \\
\hline 11 & $\begin{array}{l}\text { I would prefer the exam timetable to be more spread out so that I can allocate my study time appropriately to } \\
\text { all my modules in order to pass. }\end{array}$ & & & & & \\
\hline \multirow[t]{2}{*}{12} & $\begin{array}{l}\text { There should be summer/winter schools available for modules that are not students' elective modules and are } \\
\text { only a prerequisite for the first year, in order to give students an opportunity to pass the module instead of } \\
\text { repeating the module in the following year. }\end{array}$ & & & & & \\
\hline & Expectations of a summer/winter school module: & & & & & \\
\hline 13 & $\begin{array}{l}\text { Summer/winter schools for a module should cover the same content as the actual module and not only focus } \\
\text { on key or high-risk chapters. }\end{array}$ & & & & & \\
\hline 14 & $\begin{array}{l}\text { I am willing to pay the entire module fee for a summer/winter school that I have to attend in order for me to } \\
\text { pass the module and not repeat the module in the following year. }\end{array}$ & & & & & \\
\hline
\end{tabular}




\begin{tabular}{|c|c|c|c|c|c|c|}
\hline & Statements & $\begin{array}{c}1 \\
\text { Strongly } \\
\text { disagree }\end{array}$ & 2 & 3 & 4 & $\begin{array}{c}5 \\
\text { Strongly } \\
\text { agree }\end{array}$ \\
\hline 15 & $\begin{array}{l}\text { I am willing to pay the entire module fee for a summer/winter school; however, I will have difficulties acquiring } \\
\text { the funds and will require financial assistance in order to attend and pass the summer/winter school and not } \\
\text { repeat the module in the following year. }\end{array}$ & & & & & \\
\hline 16 & I would recommend the establishment of a summer school for Financial Accounting 188. & & & & & \\
\hline
\end{tabular}

- What would you like summer/winter schools for a module to focus on? For example:

- Theory

- Exam technique

- Question class and tutorials

- $\quad$ All of the above

Have you previously completed a summer/winter school? Yes / No / Prefer not to say

- What challenges do you think the establishment of a summer school for a year module (such as Financial Accounting 188) will have in comparison to summer/winter schools currently offered for semester modules (if any)?

- Any other comments regarding summer/winter schools? 